\title{
Air-sea fluxes of methanol, acetone, acetaldehyde, isoprene and DMS from a Norwegian fjord following a phytoplankton bloom in a mesocosm experiment
}

\author{
V. Sinha ${ }^{1}$, J. Williams ${ }^{1}$, M. Meyerhöfer ${ }^{2}$, U. Riebesell ${ }^{2}$, A. I. Paulino ${ }^{3}$, and A. Larsen $^{3}$ \\ ${ }^{1}$ Max Planck Institute for Chemistry, J.J. Becher Weg 27, 55128 Mainz, Germany \\ ${ }^{2}$ Leibniz Institut für Meereswissenschaften, IFM-GEOMAR, Marine Biogeochemie, Düsternbrooker Weg 20, 24105 Kiel, \\ Germany \\ ${ }^{3}$ Department of Biology, Jahnebakken 5, University of Bergen, P.O. Box 7800, 5020 Bergen, Norway
}

Received: 28 July 2006 - Published in Atmos. Chem. Phys. Discuss.: 10 October 2006

Revised: 10 January 2007 - Accepted: 18 January 2007 - Published: 14 February 2007

\begin{abstract}
The ocean's influence on volatile organic compounds (VOCs) in the atmosphere is poorly understood. This work characterises the oceanic emission and/or uptake of methanol, acetone, acetaldehyde, isoprene and dimethyl sulphide (DMS) as a function of photosynthetically active radiation (PAR) and a suite of biological parameters. The measurements were taken following a phytoplankton bloom, in May/June 2005 with a proton transfer reaction mass spectrometer (PTR-MS), from mesocosm enclosures anchored in the Raunefjord, Southern Norway. The net flux of methanol was always into the ocean, and was stronger at night. Isoprene and acetaldehyde were emitted from the ocean, correlating with light $\left(\mathrm{r}_{\mathrm{avcorr}}\right.$,isoprene $=0.49$; $\mathrm{r}_{\text {avcorr, acetaldehyde }}=0.70$ ) and phytoplankton abundance. DMS was also emitted to the air but did not correlate significantly with light $\left(\mathrm{r}_{\mathrm{avcorr}, \mathrm{dms}}=0.01\right)$. Under conditions of high biological activity and a PAR of $\sim 450 \mu$ mol photons $\mathrm{m}^{-2} \mathrm{~s}^{-1}$, acetone was emitted from the ocean, otherwise it was uptaken. The inter-VOC correlations were highest between the day time emission fluxes of acetone and acetaldehyde $\left(\mathrm{r}_{a v}=0.96\right)$, acetaldehyde and isoprene $\left(\mathrm{r}_{a v}=0.88\right)$ and acetone and isoprene $\left(\mathrm{r}_{a v}=0.85\right)$. The mean fluxes for methanol, acetone, acetaldehyde, isoprene and DMS were $-0.26 \mathrm{ng} \mathrm{m}^{-2} \mathrm{~s}^{-1}, 0.21 \mathrm{ng} \mathrm{m}^{-2} \mathrm{~s}^{-1}, 0.23 \mathrm{ng} \mathrm{m}^{-2} \mathrm{~s}^{-1}$, $0.12 \mathrm{ng} \mathrm{m}^{-2} \mathrm{~s}^{-1}$ and $0.3 \mathrm{ng} \mathrm{m}^{-2} \mathrm{~s}^{-1}$, respectively. This work shows that compound specific PAR and biological dependency should be used for estimating the influence of the global ocean on atmospheric VOC budgets.
\end{abstract}

Correspondence to: J. Williams

(williams@mpch-mainz.mpg.de)

\section{Introduction}

As the ocean covers some $70 \%$ of the Earth's surface area, its potential effect on atmospheric trace gases is enormous. Remarkably, the net primary production of the ocean $(48.5 \mathrm{PgC}$ $\mathrm{yr}^{-1}, \mathrm{P}=$ peta $\left.=10^{15}\right)$ is comparable to that of the terrestrial environment (56.4 $\mathrm{PgC} \mathrm{yr}^{-1}$ ) (Field et al., 1998), despite the total amount of biomass in the surface ocean being 100 times less than on land. Ocean biology influences the concentrations of dissolved gases directly (through photosynthesis and emission), and indirectly (through photochemistry of byproducts). Such processes lead to an uptake from, or an emission to, the overlying atmosphere for a suite of organic gases (e.g. $\mathrm{CO}_{2}$, DMS, isoprene, acetone). These gases are known to significantly impact the atmosphere, influencing ozone photochemistry and aerosol physics (Williams, 2004a, and references therein) even at trace concentrations. Dimethyl sulphide and isoprene have both been established as emissions from the surface ocean to the atmosphere and the distribution of these sources has been investigated by several groups (Bonsang et al., 1992; Kettle and Andreae, 2000; Palmer and Shaw, 2005). Many hundreds of atmospherically important species have been characterised and inventoried from terrestrial sources (Olivier et al., 1994; Guenther et al., 1995), but in comparison, very little work has been done on assessing the emission of volatile organic compounds from the ocean.

It was discovered quite recently that the surface ocean can play an important role in the budgets of organic trace gases, particularly oxygenated species such as acetone (propanone), methanol, and acetaldehyde (ethanal) (Singh et al., 2003). These species have been shown to be ubiquitous in the atmosphere (Singh et al., 2001) and to influence radical budgets

Published by Copernicus GmbH on behalf of the European Geosciences Union. 


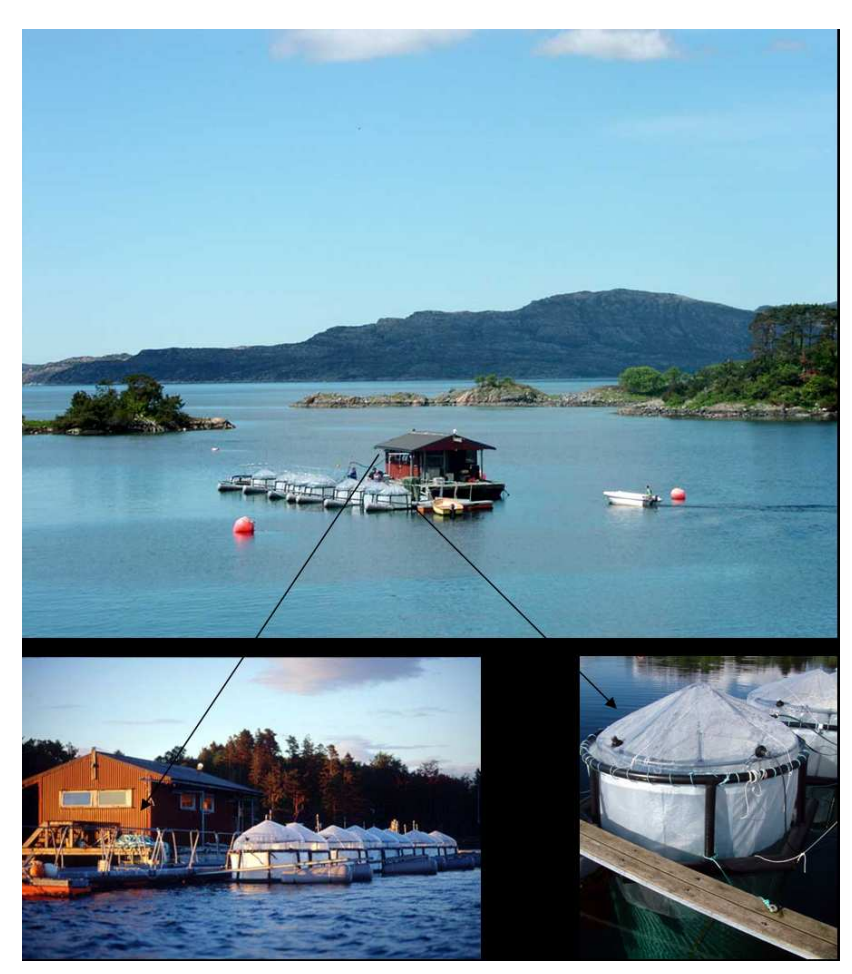

Fig. 1. View of the University of Bergen raft facility with attached mesocosms, located in a fjord $20 \mathrm{~km}$ south of Bergen. The enlarged views show the mesocosms and the raft in detail.

in the upper troposphere (McKeen et al., 1997; Tie et al., 2003; Colomb et al., 2006). Furthermore, the surface ocean has been shown to be a massive reservoir for oxygenated organic species, both indirectly from aircraft measurements (Singh et al., 2000) and directly from ship borne measurements (Williams et al., 2004b).

There have been several global budget estimates for the oxygenated species methanol (Singh et al., 2000; Galbally and Kirstine, 2002; Heikes et al., 2002), and acetone (Singh et al., 1994, 2000, 2004; de Laat et al., 2001; Jacob et al., 2002). The large range of these budget estimates (75$490 \mathrm{Tg} \mathrm{yr}^{-1}$ methanol; 37-148 $\mathrm{Tg} \mathrm{yr}^{-1}$ acetone) indicates their currently uncertain nature, and in all these budgets the role of the ocean is the most uncertain factor. In the case of methanol, there is general consensus that methanol is uptaken from the atmosphere to the ocean. The latest budget estimates by Singh et al. (2004) and Jacob et al. (2005) estimate a $10-15 \mathrm{Tg} \mathrm{yr}^{-1}$ sink accounting for approximately $20 \%$ of the global budget. It is not yet clear as to what is responsible for maintaining an under saturation of methanol in surface waters, although certain methylotrophic bacteria are known to consume methanol (Kiene, 1993). In the case of acetone, there is remarkably poor agreement concerning the effect of the ocean on the global acetone budget. Using an inverse modelling approach, Jacob et al. (2002) deduced an oceanic source of $27 \mathrm{Tg} \mathrm{yr}^{-1}$ (some $33 \%$ of a total bud- get of $95 \mathrm{Tg} \mathrm{yr}^{-1}$ ); Singh et al. (2004) estimated a small net sink (in a total budget of $95 \mathrm{Tg} \mathrm{yr}^{-1}$ ); whereas Marandino et al. (2005) extrapolate an oceanic sink of $48 \mathrm{Tg} \mathrm{yr}^{-1}$ (in a total budget of $101 \mathrm{Tg} \mathrm{yr}^{-1}$ ), from flux measurements made over the Pacific Ocean. Clearly, further measurements are required in parallel with biological parameters to elucidate these seemingly contrary findings. Moreover, significant median mixing ratios of the reactive species acetaldehyde (204 \pm 40 pptv) have been reported by Singh et al. (2003), even after the application of a pollution filter on the dataset. Despite its potential atmospheric importance, no global budget estimate of acetaldehyde has been made to date.

In this study we characterise the effect of the ocean on ambient atmospheric mixing ratios of methanol, acetone, acetaldehyde, isoprene and DMS as a function of light and a suite of biological parameters. The measurements were made under semi-controlled conditions from custom-built mesocosms deployed in the Raunefjord, Southern Norway (see Fig. 1). Mesocosm studies provide a useful interface between laboratory culture studies and open ocean surveys. While laboratory studies cannot generate the community dynamics of natural ecosystems, open ocean studies are complicated by horizontal and vertical mixing in both the air and water phases. Mesocosms therefore offer an excellent opportunity to study natural plankton communities under controlled conditions.

\section{Experimental}

\subsection{The mesocosms}

A total of nine polyethylene enclosures (hereafter referred to as mesocosms) were deployed in a fjord at the University of Bergen Marine Biological Station, $20 \mathrm{~km}$ south of Bergen, Norway. The construction and operation of such mesocosms has been described in detail elsewhere (Williams and Egge, 1998; Engel et al., 2005), hence only a brief description is given here. The polyethylene enclosures $\left(\sim 20 \mathrm{~m}^{3}\right.$ water volume; $9.5 \mathrm{~m}$ water depth; $\sim 4.3 \mathrm{~m}^{3}$ headspace volume) were filled with unfiltered, nutrient-poor, post-bloom fjord water, which was pumped from $12 \mathrm{~m}$ depth adjacent to a raft anchored in the centre of the fjord. The enclosures were covered by gas-tight tents made of ETFE foil (Foiltec, Germany), which allowed for 95\% light transmission of photosynthetically active radiation (PAR). In order to stratify the water column and avoid re-introduction of sedimented material into the surface sea layer, $0.6 \mathrm{~m}^{3}$ of freshwater was added and mixed into the upper $5 \mathrm{~m}$ of the mesocosms. Throughout the study, the upper $5 \mathrm{~m}$ layer was gently mixed by means of an aquarium pump. A phytoplankton bloom consisting of a mixture of diatoms, the coccolithophore Emiliania huxleyi, and other prymnesiophytes, was induced by adding nitrate and phosphate in the ratio of 25:1 yielding initial concentrations of approximately $15 \mu \mathrm{mol} \mathrm{L}^{-1} \mathrm{NO}_{3}^{-}$and $0.6 \mu \mathrm{mol} \mathrm{L}^{-1}$ 
$\mathrm{PO}_{4}^{3-}$. The development of the bloom is seen in the profile of Chlorophyll a and the trace gas measurements presented herein were conducted in the aftermath of the bloom (see Fig. 2).

The air flow into several mesocosms was dosed with additional $\mathrm{CO}_{2}$ in order to also study the effects of elevated $\mathrm{CO}_{2}$ on marine biology (see PeECE study website at http://peece. ifm-geomar.de). In this work, we present measurements only from the duplicate mesocosms which were flushed with ambient air, since these most closely represent the ambient atmosphere of today and are not subject to additional biological responses associated with altering dissolved $\mathrm{CO}_{2}$. Based on the rate of the ambient air inflow and the volume of the mesocosm headspace $\left(\sim 4.3 \mathrm{~m}^{3}\right)$, the total headspace-air replacement time was $191 \mathrm{~min}$ and $170 \mathrm{~min}$ for mesocosms 7 and 8 , respectively. The inflow and outflow air from both mesocosms was sampled for a suite of volatile organic compounds.

Irradiance was continuously measured every $10 \mathrm{~min}$ throughout the study by using a Li-Cor cosine sensor (LI192SA), mounted on top of the floating mesocosm laboratory.

\subsection{PTR-MS}

A proton transfer reaction mass spectrometer (PTR-MS) was employed to measure masses 33, 59, 45, 63 and 69, which have been attributed to methanol, acetone, acetaldehyde, DMS and isoprene, respectively. These identifications are in keeping with previous studies although minor contributions from other species, such as propanal to mass 59 cannot be ruled out (Lindinger et al., 1998; Williams et al., 2001). The instrument was positioned on a floating raft to which the mesocosms were attached, in a fjord that opened to the sea some $5 \mathrm{~km}$ away (see Fig. 1). Ambient air and air from the headspace of each mesocosm was drawn rapidly $\left(\sim 4.3 \mathrm{~L} \mathrm{~min}^{-1}\right)$ and continuously through $0.64 \mathrm{~cm}$ diameter and $25 \mathrm{~m}$ long Teflon lines shrouded from sunlight. The inlet residence time was less than 12 seconds. A fraction of this flow was sampled online by the PTR-MS. The entire inlet system of the PTR-MS including switching valves comprised of Teflon. Within the instrument, organic species with a proton affinity greater than water are chemically ionised by proton transfer with $\mathrm{H}_{3} \mathrm{O}^{+}$ions and the products are detected using a quadrupole mass spectrometer (Lindinger et al., 1998). Further details of the operation of the PTR-MS used here are given elsewhere (Salisbury et al., 2003).

Sequential measurements of ambient air and air from the duplicate mesocosms 7 and 8 were made for $10 \mathrm{~min}$ each, in the order - mesocosm 7, ambient air and mesocosm 8. Calibrations were performed during the campaign using a commercial gas standard (Apel-Reimer Environmental Inc.). The total uncertainties of the measurements are estimated to be $21.3 \%, 15 \%, 19 \%, 17 \%$ and $14 \%$ for methanol, acetone, acetaldehyde, isoprene and DMS, re-

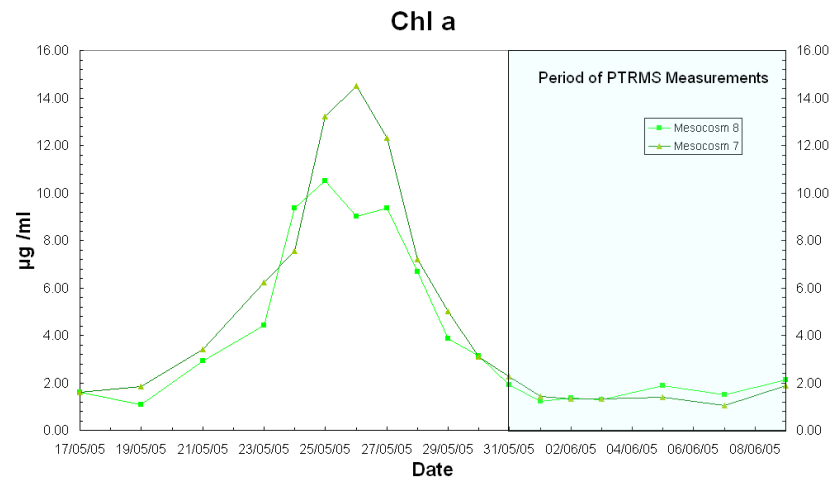

Fig. 2. Time series of Chlorophyll a in mesocosms 7 and 8 .

spectively. This includes a 5\% accuracy error inherent in the gas standard and a $2 \sigma$ precision error for all the compounds. Detection limit was defined as the $2 \sigma$ error in the instrument signal, while measuring methanol at an average mixing ratio of $1 \mathrm{nmol} \mathrm{mol}^{-1}$ and each of the other compounds at an average mixing ratio of $0.5 \mathrm{nmol} \mathrm{mol}^{-1}$. The individually calculated precision errors and detection limits were as follows, methanol $\left(16.3 \% ; 0.24 \mathrm{nmol} \mathrm{mol}^{-1}\right)$, acetone $\left(10 \% ; \quad 0.07 \mathrm{nmol} \mathrm{mol}^{-1}\right)$, acetaldehyde $(14 \%$; $\left.0.06 \mathrm{nmol} \mathrm{mol}^{-1}\right)$, isoprene $\left(12 \% ; 0.06 \mathrm{nmol} \mathrm{mol}^{-1}\right)$ and DMS (9\%; $\left.0.05 \mathrm{nmol} \mathrm{mol}^{-1}\right)$.

\subsection{Biological parameters methods}

Chlorophyll a (Chl a) was determined in 250 to $500 \mathrm{ml} \mathrm{sam}-$ ples filtered on glass fibre filters (GF/F, Whatman). For pigment extraction, filters were homogenised in plastic vials together with $1 \mathrm{ml}$ acetone $(100 \%)$ and a mixture of glass beads ( 2 and $4 \mathrm{~mm}$ ) by shaking ( $5 \mathrm{~min}$ ) in a cooled Vibrogen cell mill (Buehler, Germany). Afterwards the extracts were centrifuged $\left(5000 \mathrm{rpm}, 10 \mathrm{~min}\right.$, cooled at $\left.-10^{\circ} \mathrm{C}\right)$. This procedure corresponds, with minor modifications, to the method of Derenbach (1969).

The content of Chlorophyll-a was then determined by means of HPLC (High Performance Liquid Chromatography), using the method of Barlow et al. (1997).

Phytoplankton cell counts were performed with a FACSCalibur flow-cytometer (Becton Dickinson) equipped with an air-cooled laser providing $15 \mathrm{~mW}$ at $488 \mathrm{~nm}$ and with a standard filter set-up. The algal counts were obtained from fresh samples at high flow rate $\left(100 \mu 1 \mathrm{~min}^{-1}\right)$. The trigger was set on red fluorescence and the samples were run on the cytometer for $300 \mathrm{~s}$. Discrimination of the algal groups was based on dot plots of side-scatter signal (SSC) and pigment autofluorescence (chlorophyll and phycoerythrin).

Samples for enumeration of bacteria were fixed with glutaraldehyde $(0.5 \%$ final concentration), frozen in liquid nitrogen and stored at $-70^{\circ} \mathrm{C}$ (Marie et al., 1999a). The samples were stained with SYBR Green I (Molecular Probes Inc., Eugene, OR) and analysed according to Marie et 
Table 1. Average, Median, Standard Deviations, Minima and Maxima for Measurements of the Ambient Marine Air flushed into the Mesocosms.

\begin{tabular}{lllllll}
\hline & $\begin{array}{l}\text { Units }\left(\mathrm{nmol} \mathrm{mol}^{-1}\right) \\
\text { Ave. }\end{array}$ & Med. & Min. & Max. & $\sigma$ & $\mathrm{n}$ \\
\hline Methanol & 2.26 & 1.86 & B.D.L & 7.99 & 1.56 & 1171 \\
Acetone & 0.87 & 0.80 & 0.28 & 2.40 & 0.29 & 1228 \\
Acetaldehyde & 0.60 & 0.55 & B.D.L & 3.96 & 0.45 & 1099 \\
Isoprene & 0.18 & 0.18 & B.D.L & 2.38 & 0.17 & 1123 \\
DMS & 0.17 & 0.40 & B.D.L & 1.15 & 0.18 & 651 \\
\hline
\end{tabular}

B.D.L $=$ Below Detection Limit

al. (1999b). The discrimination of bacteria groups was based on groups observed in scatter plots of SSC signal versus green DNA-dye (SYBR Green) fluorescence. Fluorescence beads (Molecular Probes) with a diameter of $0.95 \mu \mathrm{m}$ were added to each sample analysed as an internal reference. Data files were analyzed using EcoFlow (version 1.0.5, available from the authors).

\section{Results}

\subsection{General trends - gas phase species}

Figure 3 shows a time series for measurements of methanol, acetone, acetaldehyde, isoprene and DMS measured as masses $33,59,45,69$, and 63, respectively. In each case the inflowing ambient air mixing ratio is plotted with the measurements from within mesocosms 7 and 8. Measurements of the inflowing ambient air, including average, median and standard deviation are summarized in Table 1. Variability in the ambient air was highest for methanol followed by acetaldehyde, acetone, isoprene and DMS (see $\sigma$ values in Table 1). For all species, good agreement can be seen between the two duplicate mesocosms. Where the mixing ratios of a particular species in the mesocosm air were significantly lower than ambient air, we infer that an uptake occurred into the seawater. Conversely when mesocosm air mixing ratios were higher than the inflowing ambient air, an emission from seawater into the air was deduced.

Diel cycles were seen in the mesocosms for acetone, acetaldehyde and isoprene, which exhibited maxima and minima typically from 12:00 p.m.-04:00 p.m. and 12:00 a.m.08:00 a.m., respectively. In contrast, methanol showed no clear diel cycle in the mesocosms, the variation and absolute values of the mesocosm data being generally suppressed with respect to the ambient air. DMS mixing ratios in the mesocosm air were observed to be generally higher in the evening rather than daytime. We investigate the light and biology dependence of these emissions and uptakes in Sect. 3.2.
3.2 Fluxes of organic species in relation to light (PAR) and biological parameters

At the outset, it should be noted that the emission and uptake fluxes reported here represent the net fluxes from seawater to air and vice versa, inside the mesocosm. Hence the fluxes may be the resultant of separate, strong sinks and sources within the mesocosm system.

Fluxes of the various VOCs were calculated according to Eq. (1),

$\mathrm{F}_{\mathrm{voc}}=\frac{Q}{A}\left(m_{\mathrm{in}, \mathrm{voc}}-m_{\mathrm{out}, \mathrm{voc}}\right) \frac{M_{\mathrm{voc}}}{V_{m}}$

where $\mathrm{F}_{\mathrm{voc}}$ is flux of the VOC in $\mu \mathrm{g} \mathrm{m}^{-2} \mathrm{~s}^{-1}, m_{\mathrm{in}, \mathrm{voc}}$ and $m_{\text {out, voc }}$ are the VOC mixing ratios $\left(\mathrm{nmol} \mathrm{mol}^{-1}\right)$ in the inflowing ambient marine air and mesocosm air respectively, $Q$ is the flow rate of the ambient air into the mesocosm in $\mathrm{m}^{3} \mathrm{~s}^{-1}, \mathrm{~A}$ is the surface area of the seawater enclosed by the mesocosm in $\mathrm{m}^{2}, \mathrm{M}_{\mathrm{voc}}$ is the molecular weight of the VOC in $\mathrm{kg} \mathrm{kmol}^{-1}$ and $\mathrm{V}_{m}$ is the molar gas volume in $\mathrm{m}^{3} \mathrm{kmol}^{-1}$ $(=23.233$ at $1013.25 \mathrm{hPa}$ and $283 \mathrm{~K})$.

Figure 4 depicts the time series of the VOC fluxes and PAR in the duplicate mesocosms 7 and 8 while Table 2 gives a summary of the averages, medians and standard deviations of the VOC fluxes in the duplicate mesocosms.

Figure 5 shows daily plankton cell counts of the coccolithophore Emiliania huxleyi, the cyanobacterium Synechococcus $s p$., other nano and picophytoplankton and freeliving heterotrophic bacteria. The trace gas measurements covered two subsequent phases of the phytoplankton bloom, from 31 May-5 June - the final phase of bloom decline, and from 6 June-10 June - a post-bloom phase of low phytoplankton standing stocks characterized by an increase in cyanobacterial cell numbers.

The photosynthetically active radiation (PAR) generally ranged from 0 to $1500 \mu \mathrm{mol}$ photons $\mathrm{m}^{-2} \mathrm{~s}^{-1}$ on most days (Fig. 4). Due to overcast conditions significantly lower daily maxima of ca. $400 \mu \mathrm{mol}$ photons $\mathrm{m}^{-2} \mathrm{~s}^{-1}$ occurred on the 4 and 10 June.

From Figs. 4, 5 and Table 2 we note that there is good consistency in the magnitude and direction of the fluxes as 
Table 2. Comparison of Fluxes in the duplicate mesocosms 7 and 8.

\begin{tabular}{lllllll}
\hline & $\begin{array}{l}\text { Units }\left(\mathrm{ng} \mathrm{m}^{-2} \mathrm{~s}^{-1}\right) \\
\text { Ave.(7) }\end{array}$ & Ave.(8) & Med.(7) & Med.(8) & $\sigma(7)$ & $\sigma(8)$ \\
\hline Methanol (U) & 0.33 & 0.39 & 0.26 & 0.27 & 0.29 & 0.30 \\
Acetone (U) & 0.08 & 0.10 & 0.05 & 0.07 & 0.06 & 0.08 \\
Acetone (E) & 0.21 & 0.26 & 0.19 & 0.34 & 0.23 & 0.29 \\
Acetaldehyde (E) & 0.34 & 0.49 & 0.19 & 0.26 & 0.49 & 0.70 \\
Isoprene (E) & 0.14 & 0.14 & 0.12 & 0.12 & 0.12 & 0.17 \\
DMS (E) & 0.30 & 0.35 & 0.30 & 0.27 & 0.17 & 0.29 \\
\hline
\end{tabular}

$\mathrm{U}=\mathrm{Uptake}$ from atmosphere to seawater; $\mathrm{E}=$ Emission from seawater to atmosphere

well as the biological parameters in the two mesocosms. The fluxes of the individual organic compounds are examined in detail in the subsequent sections.

\subsubsection{Methanol}

Throughout the experiment, the net flux of methanol was always into the seawater from the mesocosm air above it. Thus methanol was uptaken both during the day and at night. The average of the Pearson linear correlation coefficients in the duplicate mesocosms (hereafter referred to as $r_{a v c o r r}$ ), calculated for the methanol uptake fluxes and the photosynthetically active radiation (PAR) was 0.18. The period from 31 May-5 June (phase of bloom decline) had stronger methanol uptake compared to 6 June-10 June (post-bloom phase with low phytoplankton abundance). Methanol uptake was generally higher during night-time, indicating that it was not driven by photosynthetic activity. The mean flux in both mesocosms calculated using median values was $-0.26 \mathrm{ng} \mathrm{m}^{-2} \mathrm{~s}^{-1}$, the negative value indicating the direction from air to seawater.

\subsubsection{Acetone}

During the daylight sections of the experiment, acetone was emitted from the seawater to the air above it, if PAR exceeded $450 \mu \mathrm{mol}$ photons $\mathrm{m}^{-2} \mathrm{~s}^{-1}$, while at night it was always uptaken from the air to the seawater. The acetone flux shows good correlation with PAR $\left(\mathrm{r}_{\mathrm{avcorr}}\right.$, acetone $\left.=0.70\right)$. Furthermore, the emission fluxes were higher in the phase of bloom decline with still relatively high phytoplankton abundances (31 May-5 June) compared to the low biomass postbloom phase (6 June-10 June). The average of the median uptake fluxes and emission fluxes (uptake from air to sea water and emission from sea water to air) in both mesocosms was $-0.06 \mathrm{ng} \mathrm{m}^{-2} \mathrm{~s}^{-1}$ and $0.27 \mathrm{ng} \mathrm{m}^{-2} \mathrm{~s}^{-1}$, respectively. Overall for the entire measurement period, the flux was an emission of $0.21 \mathrm{ng} \mathrm{m}^{-2} \mathrm{~s}^{-1}$.

\subsubsection{Acetaldehyde and isoprene}

Acetaldehyde and isoprene were emitted from the seawater to the overlying air throughout the measurement period, with almost no evidence of seawater uptake. The fluxes of acetaldehyde and isoprene show strong correlation with each other $\left(\mathrm{r}_{\mathrm{avcorr}}=0.86\right)$. The flux of acetaldehyde shows greater correlation with PAR ( $r_{\text {avcorr, acetaldehyde }}=0.70$ ) compared to isoprene flux and PAR ( $\left.\mathrm{r}_{\text {avcorr,isoprene }}=0.49\right)$. There was a decrease in the flux of both acetaldehyde and isoprene during the second phase of the measurement period, from 6 June-10 June. Mean emission flux strengths calculated from median values in the duplicate mesocosms were $0.23 \mathrm{ng} \mathrm{m}^{-2} \mathrm{~s}^{-1}$ and $0.12 \mathrm{ng} \mathrm{m}^{-2} \mathrm{~s}^{-1}$ for acetaldehyde and isoprene, respectively.

\subsubsection{Dimethyl sulphide (DMS)}

In both mesocosms, DMS was always emitted from the seawater to the air above it. DMS fluxes showed negligible correlation with PAR $\left(\mathrm{r}_{\text {avcorrdms }}=0.01\right)$. Emission occurred at similar rates irrespective of light intensity, as seen on 4 June, which was particularly overcast. Remarkably, among all the measured organic species' fluxes, only the DMS flux did not decrease in the second phase i.e. from 6 June-10June. The mean DMS emission flux calculated using median values from both mesocosms was $0.3 \mathrm{ng} \mathrm{m}^{-2} \mathrm{~s}^{-1}$.

\section{Discussion}

This is the first time that air-sea fluxes of organics have been analyzed and quantified during a mesocosm experiment. From the point of view of trace gas exchange, the mesocosm is a transparent tent, set over an area of ocean surface (circa $3 \mathrm{~m}^{2}$ ) and extending from $1.5 \mathrm{~m}$ over the surface to 9.5 below. The tent contains a pocket of gas which is ventilated with ambient air at a constant flow (residence time of the air is $191 \mathrm{~min}$ for mesocosm 7 and $170 \mathrm{~min}$ for mesocosm 8). The mesocosm experiment differs markedly from the static chamber flux experiments often conducted in soil and plant science. Most importantly, the uppermost 

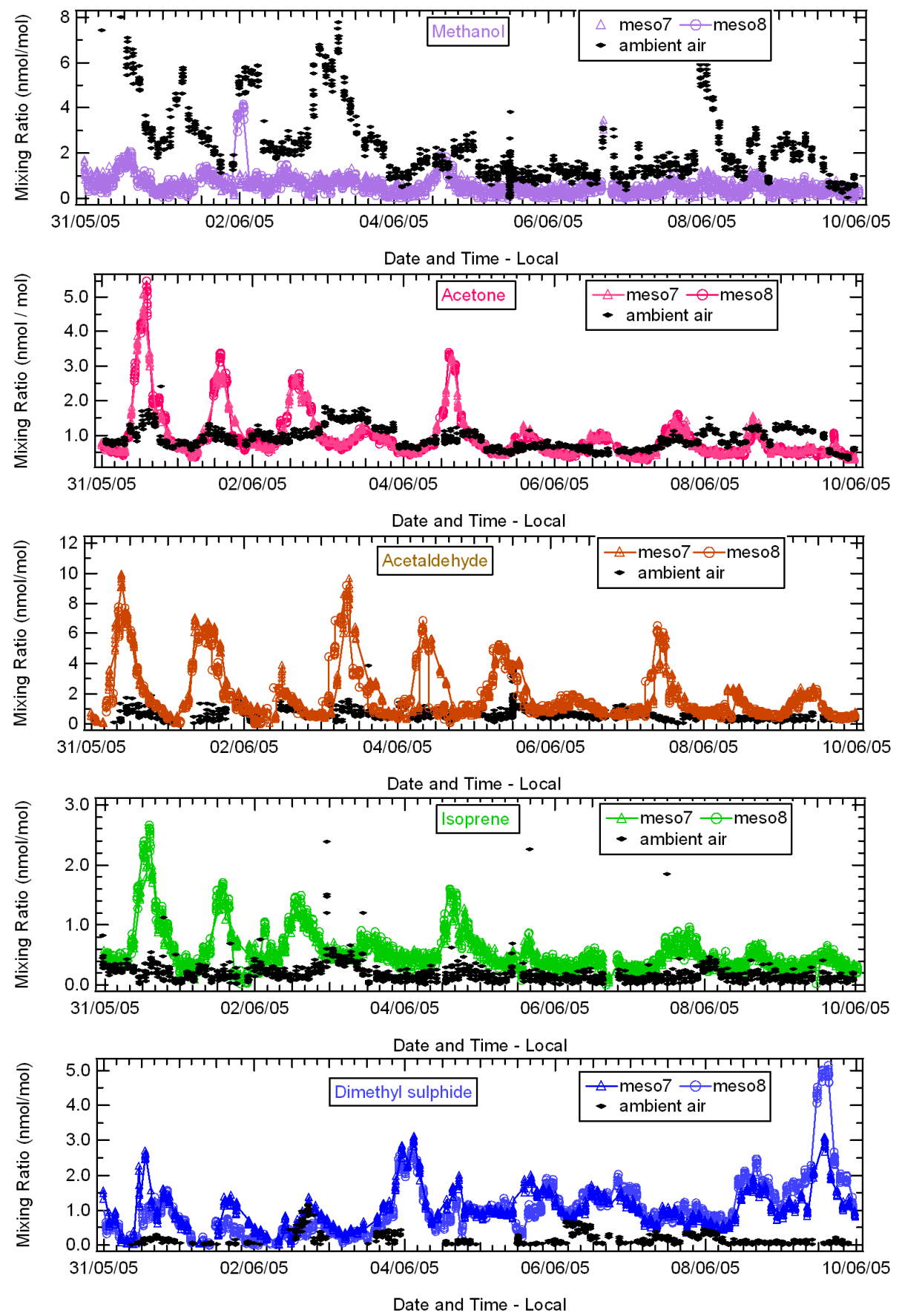

Fig. 3. Time series of methanol, acetone, acetaldehyde, isoprene and DMS from inside and outside the duplicate mesocosms 7 and 8.

$5 \mathrm{~m}$ of seawater in the mesocosm is kept well mixed (see Fig. 6) by use of an aquarium pump (constant flow) and it is from this volume that chlorophyll and DOC measurements are made. In the "real" world many physical parameters may affect the sea-air flux of a given species, for example, the wind speed (as was shown by Carpenter et al., 2004) and mixing down from the ocean uppermost mixed layer. Thus, in the open ocean mixing, dispersal and advection of the water mass complicate the interpretation of the data. On the other hand, the mesocosm system has low, almost constant air flow, subdued wave activity and possible wall effects from the enclosures, which might cause deviance from conditions in the natural environment. However, the beauty of the mesocosm experiment is that the wind speed and the downward 


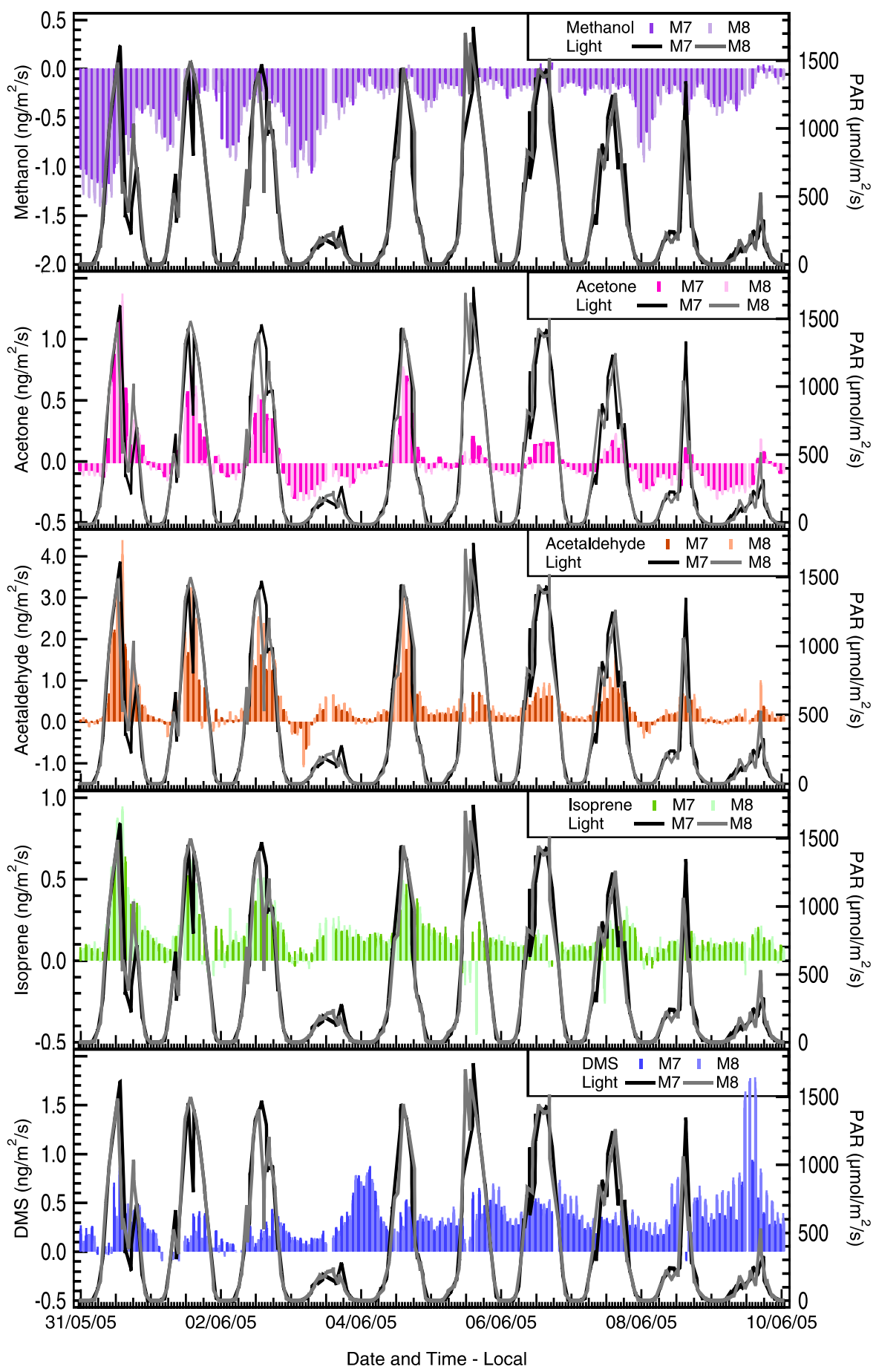

Fig. 4. Flux profiles of methanol, acetone, acetaldehyde, isoprene, DMS and photosynthetically active radiation (PAR) as a function of time in the duplicate mesocosms 7 and 8 .

mixing are kept as constant as possible by means of a constant air flow and the effective mixing of the $0-5 \mathrm{~m}$ seawater layer, thus allowing other potentially controlling parameters to be investigated. Particularly suited for investigation in the mesocosm system is the significance of: a) ocean bi- ology producing or consuming organic trace species in the seawater, b) that organic chemicals in the seawater (either directly or indirectly produced by the biology) may be photochemically degraded abiologically to organic gases that subsequently escape to the air. A considerable advantage of 

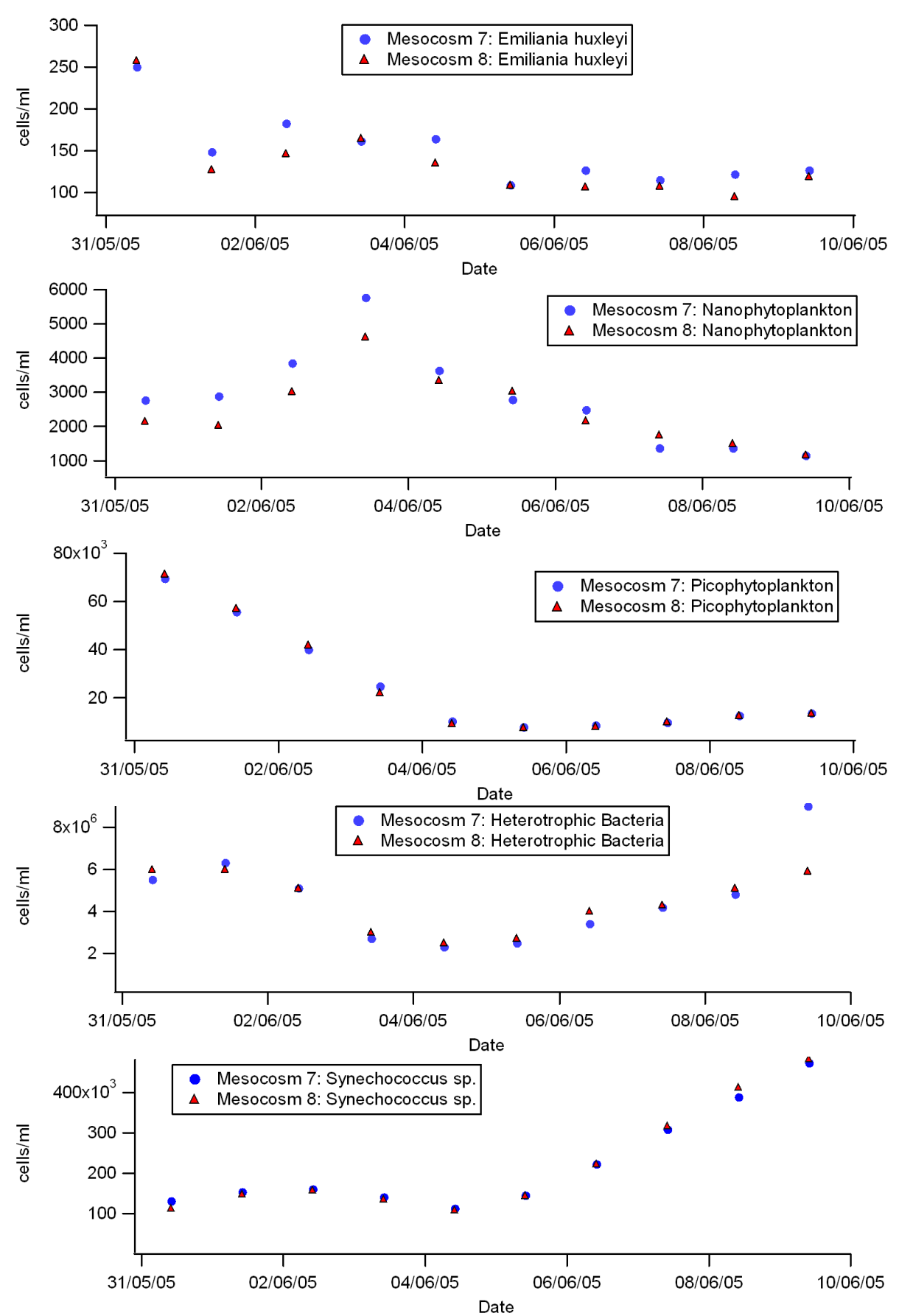

Fig. 5. Daily variation of selected phytoplankton and bacteria over the measurement period for the duplicate mesocosms 7 and 8 .

the mesocosm experiment over laboratory studies of single plankton species is that the plankton ecosystem is investigated as a whole, and possible interactions between plankton species (community dynamics) can occur. Furthermore within the mesocosm experiment the biology can be monitored, as opposed to "real world" aircraft studies (e.g. Singh et al., 2003) or coastal studies (e.g. Carpenter et al., 2004).
While previous oceanic flux studies of these compounds have been based on either air-sea flux models (Liss and Mervilat, 1986) or inverse modelling (Jacob et al., 2002; de Laat et al., 2001), in this study we infer fluxes from the difference in direct measurements of the air, before and after controlled interaction with the underlying seawater. Thus, assumptions and uncertainties pertaining to the model based studies are absent in this approach. 


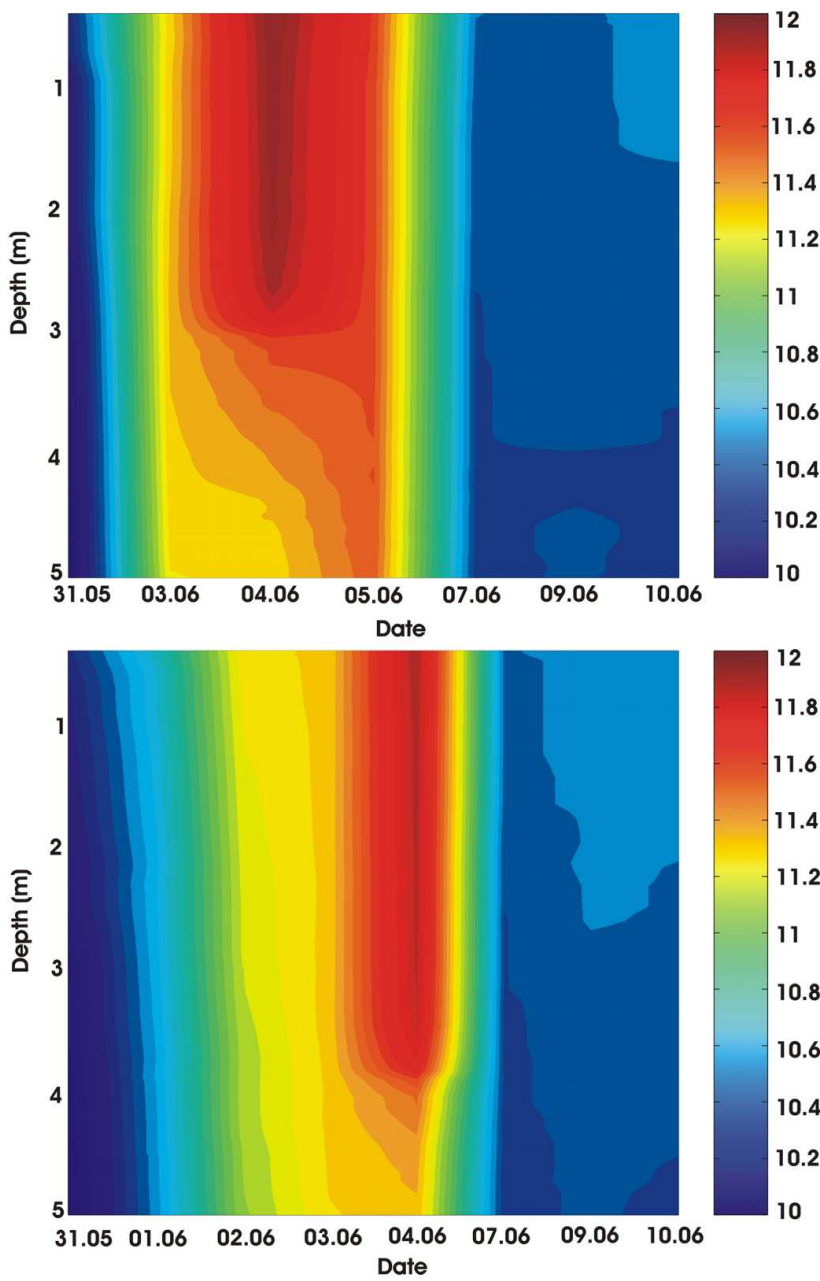

Fig. 6. Daily (11:00 a.m.) depth profiles of temperature in the waters (upper $5 \mathrm{~m}$ ) of mesocosm 7 (above) and mesocosm 8 (below).

Before discussing the correlation of the VOC fluxes with light and ocean biology we would like to examine the potential effects of parameters such as friction velocity, the changing temperature in the mesocosm waters (by possible "greenhouse" heating effect) and possible persistent surface microlayer formation. In the mesocosm system, the influence of any dynamic parameter (e.g. friction velocity) on the VOC fluxes is constant because the air flow through the system is not changing and the water in the first $5 \mathrm{~m}$ is constantly mixed. Thus the observed variation in the VOC fluxes cannot be accounted for, in terms of such dynamic parameters. The daily depth profile of mesocosm water temperature is shown in Fig. 6 (the measurements were taken at 11:00 a.m. everyday when PAR is almost at its maximum value for the day, see Fig. 4). Note that the temperature in the water of the mesocosms did not differ significantly for the "sunny" days compared to the overcast days on the 3, 8 and 9 June. This is because the wind buffeting and wave action on the sides of the mesocosm tents coupled with the constant ambi-
Table 3. Change in Henry's law partitioning due to change in temperature of the mesocosm waters.

\begin{tabular}{lll}
\hline Compound & $\begin{array}{l}\text { Henry's law constant } \\
\text { (Cwater/Cair) }\end{array}$ & Temperature (K) \\
\hline Methanol & 13003 & 283 \\
Methanol & 11519 & 285 \\
Acetone & 1430 & 283 \\
Acetone & 1279 & 285 \\
Acetaldehyde & 969 & 283 \\
Acetaldehyde & 862 & 285 \\
\hline
\end{tabular}

ent air flushing rate of $30 \mathrm{~L} / \mathrm{min}$ ensures good mixing within the mesocosm system and prevents the accumulation of thermal energy quite efficiently. For the maximum change in the mesocosm water temperature of $2^{\circ} \mathrm{K}$ observed between different days at 11:00 a.m. (see Fig. 6), the change in the Henry's law partitioning between the aqueous and gas phase for the OVOCs is shown in Table 3. These results clearly show that the maximum temperature effect would cause only a $13 \%$ relative concentration change for methanol, $12 \%$ relative concentration change for acetone and $12.4 \%$ relative concentration change for acetaldehyde concentrations in the gas phase based on the change in the Henry's law partitioning. The relative change in the mixing ratios, between a diel minima and maxima is, however, much greater varying between 500\%-1500\% depending on the VOC and the biological phase (see Fig. 3). Moreover a diel variation time series generated purely by the temperature effect should show no significant difference between the two biological phases. The issue of a persistent surface microlayer is an important one. Such a surface microlayer owing to its surfactant nature, would offer resistance to gas exchange between the bulk water layer and the atmosphere and also be more enriched in Dissolved Organic Matter (DOM) compared to the bulk water, due to inefficient transport and inhibited mixing. In the experimental set up, water in the first $5 \mathrm{~m}$ was continuously circulated by means of an aquarium pump and the outlet of the pump was set near the surface in order to inhibit microlayer formation. The fact that species produced in the bulk water such as isoprene, mirror PAR (see Fig. 4) without any significant time phase shift, support the theory that the combined effects of the waves buffeting the mesocosm tents and the internal mixing within the upper $5 \mathrm{~m}$ water column in the manner described earlier, prevent the occurrence of a persistent surface microlayer.

From the observations presented in Sect. 3.2 we now examine the light and biology dependence of our derived fluxes within the context of the available literature. In this study, it is extremely difficult to implicate specific biological parameters for the emission or uptake of a particular trace gas, as the biological parameters were measured only once a day and the 

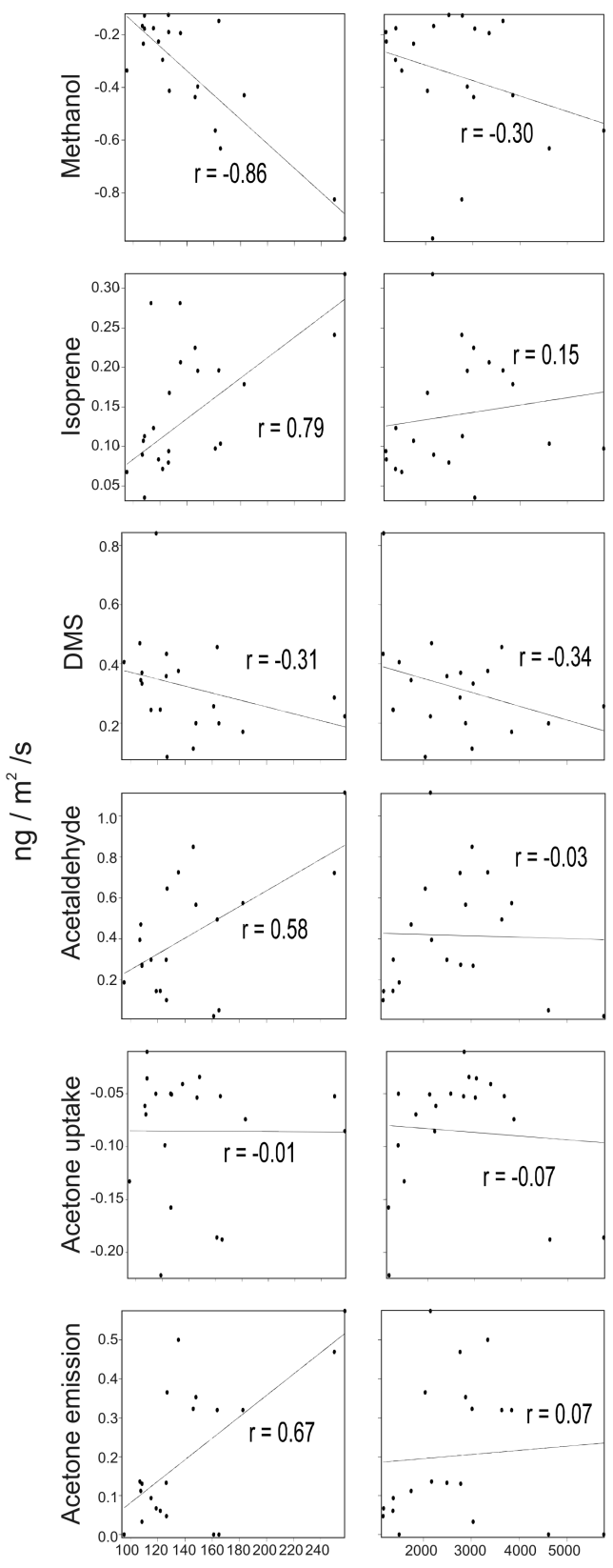

Emiliania huxleyi

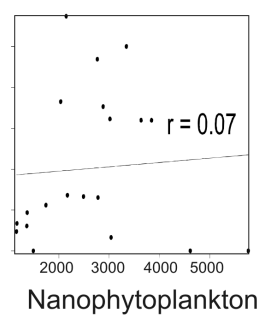

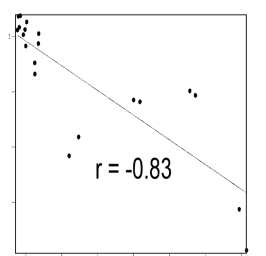
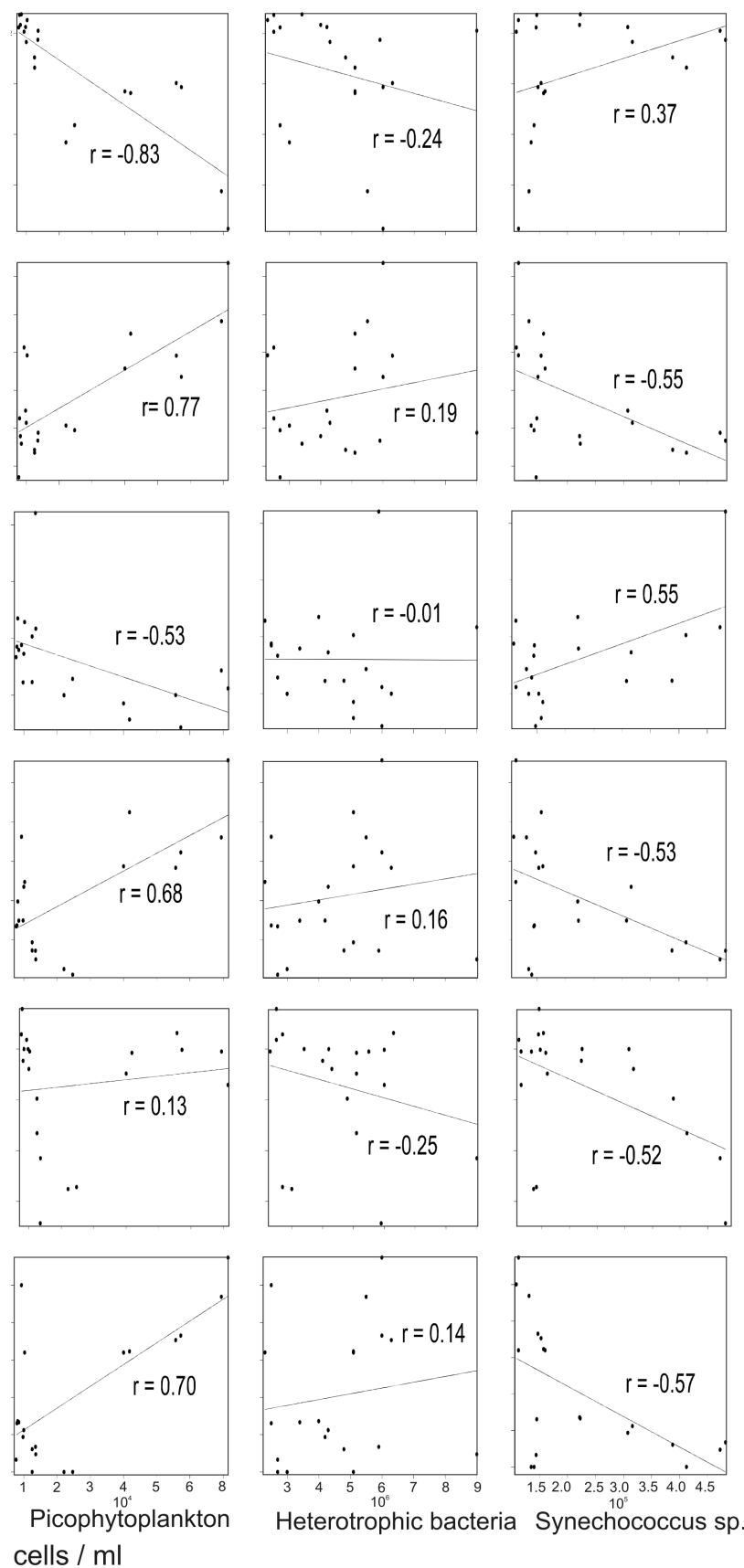

cells / ml

Fig. 7. Regression lines and correlation coefficients (r) between daily averaged VOC fluxes (individual rows) and daily abundance of the biological parameters (individual columns) using data from both mesocosms.

measured flux represents a net process due to possibly different sources and sinks. Nevertheless to give some idea about possible correlations between the VOC fluxes and the few biological parameters measured in this study, we have done a linear regression analysis of the daily averaged VOC flux (row) against the measured biological parameters (column) in both the mesocosms (see Fig. 7). For acetone, the daily emission flux and daily uptake flux has been treated individually. While interpreting the correlations, it should be borne in mind that at different stages in their life cycle, biological organisms can exhibit different responses and that community dynamics can cause coincidental correlations between individual VOCs and the biological parameters. Furthermore, some of the measured biological parameters are individual species such as Emiliania huxleyi and Synechococuss sp. while the others like nano plankton (size class), pico plankton (size class) and heterotrophic bacteria are bulk parameters that comprise of more than one species, so appropriate 
care should be taken while interpreting the significance of the correlations. Moreover, the chlorophyll content and hence photosynthetic activity depends to considerable degree on the cell size of the autotrophic species, so one cell of Emiliania huxleyi will be more potent in producing isoprene (a by product of photosynthesis) than one cell of the other smaller autotrophic species.

Day-time emission of acetone from seawater to the air occurred during the period of bloom decline, when phytoplankton biomass was still high, and comparatively low or absent during the post-bloom period of low phytoplankton abundances. Daily averaged acetone emissions seem to correlate positively with the measured daily abundance of Emiliania huxleyi $(\mathrm{r}=0.67)$ and picophytoplankton $(\mathrm{r}=0.70)$ while there seems to be negative correlation with Synechococcus $s p . \quad(\mathrm{r}=-0.57)$ (see Fig. 7). Light-dependency of acetone emission was indicated on 4 June, when maximum light intensities below $\sim 350 \mu \mathrm{mol}$ photons $\mathrm{m}^{2} \mathrm{~s}^{-1}$ shifted daytime acetone emission to acetone uptake. Can we reconcile these results with the study by Marandino et al. (2005), which reported that acetone is always uptaken from the air to the seawater? It is well established that dissolved organic matter produces acetone by solar irradiation (Zhou and Mopper, 1997). During both phases of plankton succession covered by our measurements, i.e. from 31 May5 June and 6 June-10 June, the dissolved organic matter (DOM) in the seawater did not show significant variance. Concentrations of dissolved organic carbon (DOC), nitrogen (DON) and phosphorus (DOP) were more or less constant during the measurement period with mean values of DOC $=100 \pm 7 \mu \mathrm{mol} \mathrm{L}^{-1}$; DON $=8 \pm 3 \mu \mathrm{mol} \mathrm{L}^{-1}$ and DOP $=0.26 \pm 0.04 \mu \mathrm{mol} \mathrm{L}^{-1}$ (J. Wohlers, personal communication, 2007). However, since the second phase had considerably less emission of acetone (see Figs. 4 and 5), despite similar PAR and DOM concentrations as during the first phase, the implication is that acetone production in seawater is biologically mediated and light dependent. In the absence or under low activity of the relevant production pathway, acetone consumption in seawater can exceed its production, leading to net acetone uptake by the ocean. This was the situation during the second phase of this study and may have been the cause during the study of Marandino et al. (2005) in the oligotrophic N. W. Pacific.

Net uptake of methanol from air into seawater appears to be attenuated by light, and biological dependence can be inferred from the decrease in the second phase, as plankton abundance and biomass declined. Of course the methanol uptake might have decreased simply because the water was under saturated in the beginning and became gradually more saturated towards the end of the experiment. If uptake was driven solely by physical undersaturation, the same trend would have been also seen in the acetone profiles (see Figs. 3 and 4). Let us nonetheless consider this hypothesis further. The well mixed mesocosm water volume is $\sim 15 \mathrm{~m}^{3}$. In order to saturate this volume of water at $283^{\circ} \mathrm{K}$, and assuming there is absolutely no methanol in the water to start with; one would need $214 \mathrm{mg}$ of methanol (Taking $\mathrm{H}=10000$ and Cair $=1 \mathrm{nmol} / \mathrm{mol}$ ). Using an uptake flux of $1 \mathrm{ng} / \mathrm{m}^{2} / \mathrm{s}$ (a generous value as can be seen from Figs. 3 and 4), during the period 17 till 30 May, we calculate that $\sim 1.2 \mathrm{mg}$ methanol would have been available for dissolution in this 14 day period, indicating that based on this criteria alone, the mesocosm water would still be significantly undersaturated before we commenced our measurements with the PTRMS on 31 May. Now, if the mesocosm waters' undersaturation was just a function of "physically driven" undersaturation then there should have been a constant decrease in the uptake flux of methanol over time, because the degree of undersaturation would decrease. What we see however is that on the afternoon of 2 June and 9 June, even for similar mixing ratios of methanol in the ambient air of around $2 \mathrm{nmol} / \mathrm{mol}$, the uptake flux of methanol is in fact more than 1.6 times higher on 9 June. Clearly this is inconsistent with the notion of an undersaturation driven solely by physical parameters and suggests a possible biological contribution to the maintenance of undersaturation in the mesocosm water. What we are suggesting here is that surface waters in the mesocosm are in fact close to equilibrium and that the undersaturation is driven by the biological uptake. A comparison of the deposition velocity found by Carpenter et al. (2004) $\left(0.02-0.33 \mathrm{~cm} \mathrm{~s}^{-1}\right.$; best estimate $\left.=0.09 \mathrm{~cm} \mathrm{~s}^{-1}\right)$ to that observed in our mesocosm study (circa $0.05 \mathrm{~cm} \mathrm{~s}^{-1}$ ) shows reasonable agreement. We interpret the deposition velocity of methanol found by Carpenter et al. (2004) as not indicating an uptake entirely dominated by aerodynamic resistance (interpreted as the turbulent resistance in the atmosphere) even at the reasonably high wind speeds of $8 \mathrm{~m} \mathrm{~s}^{-1}$. If this were the case (i.e. surface resistance is unimportant) then deposition velocities would be higher (similar to those of $\mathrm{HNO}_{3}$ ca. $0.5-1 \mathrm{~cm} \mathrm{~s}^{-1}$ ). The comparison of modeled and measured values for methanol wind speed dependencies given by Carpenter et al. (2004) do not show a particularly good match, especially at low wind speeds despite being described a good agreement, perhaps because the model is not fully describing the processes in play and ocean biology contributes to the uptake. As mentioned in the results section, we also observed reduced uptake during daylight hours in the first phase, which was characterized by higher plankton abundance. Heikes et al. (2002) report that methanol has been observed in the headspace of laboratory phytoplankton cultures. Either the biological uptake of methanol from air to seawater is less during the day, or methanol is produced in seawater by phytoplankton during the day or both processes together result in the reduced uptake of methanol, from air to seawater during the day. The second phase has higher Synechococcus $s p$ and free living heterotrophic bacteria but the methanol uptake flux does not increase. This seems to suggest that the cyanobacteria Synechococcus $s p$ and the free living heterotrophic bacteria do not consume methanol significantly under these conditions $(|\mathrm{r}|<0.38$ for both; Fig. 7). 
Surprisingly, methanol uptake shows correlation with Emiliania huxleyi and picophytoplankton $(|\mathrm{r}|=0.86$ and $|\mathrm{r}|=0.83$, respectively). We would like to stress that for reasons outlined earlier, this does not necessarily imply that Emiliania huxleyi and picophytoplankton uptake methanol by night, although based on our dataset it seems to be a possibility.

Acetaldehyde and isoprene are generally emitted from the seawater to the overlying air. The emissions correlate with both photosynthetically active radiation, as well as the measured biological parameters $(\mathrm{r}=0.58$ for acetaldehyde with Emiliania huxleyi, r=0.79 for isoprene with Emiliania huxleyi and $\mathrm{r}=0.68$ for acetaldehyde with picophytoplankton and $\mathrm{r}=0.77$ for isoprene with picophytoplankton), with decrease in the second phase of the measurements. It should also be noted that some isoprene and acetaldehyde production occurs under overcast conditions and even at night. Like acetone, acetaldehyde is also produced by the photochemical degradation of dissolved organic matter (DOM) in seawater (Zhou and Mopper, 1997), while planktons are known to produce isoprene (Milne et al., 1995). The high degree of correlation between isoprene and acetaldehyde for the entire study $(\mathrm{r}=0.86)$ and the decrease in both isoprene and acetaldehyde emissions in the second phase, coupled with the insignificant variance in the dissolved organic matter (DOM) during both phases, suggest that there might be some biologically mediated production of acetaldehyde in seawater, from which emission then occurs to the overlying air.

DMS emissions do not seem to depend on light and the emission rate is quite comparable in both phases. It is well established that DMS is produced in seawater both by direct release from phytoplankton and by bacteria and zooplankton mediated grazing (Dacey and Wakeham, 1986; Gabric et al., 2001). Further, Nguyen et al. (1998) have reported appreciable DMS production in seawater during the senescence phase of phytoplankton. Thus, DMS emission in the first phase is probably due to direct release from phytoplankton while grazing processes seem to be responsible for the DMS emission during the second phase.

It is also useful to try and look at correlations amongst the emission fluxes of isoprene, acetone, acetaldehyde, DMS and the uptake fluxes of acetone and methanol with each other during day and night conditions, to try and gauge if they might have common mechanisms linked to their uptake and/or emissions. The Pearson linear correlation coefficient $\left(\mathrm{r}_{a v}\right)$ for all possible pairs among the measured VOC fluxes is shown in Table 4. The strongest correlations seem to be for the daytime emission fluxes of acetone and acetaldehyde $\left(\mathrm{r}_{a v}=0.96\right)$, acetaldehyde and isoprene $\left(\mathrm{r}_{a v}=0.88\right)$ and acetone and isoprene $\left(\mathrm{r}_{a v}=0.85\right)$. Since isoprene is widely established as a biogenic emission, these correlation values support our hypothesis that acetone and acetaldehyde emissions have some biological dependence. The other notable feature is that at least for conditions during our study, DMS emission does not correlate with any of the other VOC fluxes.
In Table 5, we compare the mixing ratios and fluxes measured here with previous studies on methanol, acetone, acetaldehyde, isoprene and DMS in the marine boundary layer. The general level of the ambient air mixing ratios of the oxygenates presented here are consistent with earlier studies, while for isoprene and DMS, they are somewhat higher. Proton transfer reaction mass spectrometry measurements are upper limit estimates because of possibly more than one species contributing to the measured mass. It should be noted that the high mixing ratios of isoprene and DMS in the ambient air were probably due to a local source of macro algae, which were growing near the raft but outside the mesocosms. Isoprene might additionally have been impacted by trees on the coast and the nearby islands.

The relative abundances of the organic trace gases reported in this work and measured using the same instrument, fit with the trend discerned from measurements in previous studies (Zhou and Mopper, 1993; Mao et al., 2006, and other references in Table 5). The trend is: methanol $>$ acetone $>$ acetaldehyde $>$ isoprene $\sim$ DMS. The reported median values also show that the sum of the oxygenates is approximately six times higher than the sum of isoprene and DMS in the marine boundary layer. Interestingly, when fluxes are compared, the sum of the fluxes of oxygenated VOCs $(0.23+0.27-0.26)$ is almost a factor of two smaller compared to the sum of isoprene and DMS $(0.12+0.3)$.

Compared with direct methanol, acetone and acetaldehyde fluxes reported from a terrestrial pine plantation (Karl et al., 2005), the oceanic fluxes reported here and in previous works (see Table 5) are 2-3 orders of magnitude lower.

Before we discuss the results of a "tentative global extrapolation" for the VOC fluxes measured in this study, we wish to highlight the associated uncertainties of the employed approach. As mentioned earlier, the mesocosm is an artificial set up with low and almost constant wind speed, possible wall losses and subdued wave activity, conditions that may represent significant deviance from "natural" oceanic conditions. For example, methanol uptake flux may be enhanced under the mesocosm conditions while DMS emission flux may be underestimated. Wall losses in the mesocosm cannot be ruled out but if they were the dominant player, one would have seen uptake all the time, i.e. ambient air would be stripped of the compound in the mesocosm by the walls and not the sea. The two most polar compounds we examine are methanol and acetone. While we do observe uptake with methanol, acetone clearly shows emission as well. The wall loss also does not account for the flux changes relating to biology or light. Stratification and mixing of the water column in the mesocosms is designed to simulate open ocean conditions. Stratification prevents re- introduction of sedimented material into the surface sea layer and mixing ensures efficient transport between the bulk and surface waters. Consequently, we believe that parameters associated with the mesocosm design are not the dominant factors controlling the VOC fluxes in the mesocosm, rather ocean biology and 
Table 4. Pearson Correlation Coefficient $\left(\mathrm{r}_{a v}\right)$ between the VOC fluxes.

\begin{tabular}{llllll}
\hline & Methanol & Acetone & Acetaldehyde & Isoprene & DMS \\
\hline Day & & & & & \\
Methanol & 1 & -0.19 & -0.15 & -0.28 & 0.2 \\
Acetone & - & 1 & 0.96 & 0.85 & 0.01 \\
Acetaldehyde & - & - & 1 & 0.88 & -0.01 \\
Isoprene & - & - & - & 1 & 0.02 \\
DMS & - & - & - & - & 1 \\
Night* & & & & & \\
Methanol & 1 & 0.36 & 0.44 & 0.24 & 0.29 \\
Acetone & - & 1 & 0.64 & 0.45 & 0.01 \\
Acetaldehyde & - & - & 1 & 0.58 & 0.26 \\
Isoprene & - & - & - & 1 & 0.23 \\
DMS & - & - & - & - & 1 \\
\hline
\end{tabular}

$+=$ Day defined as whenever PAR $>100 \mu \mathrm{mol} \mathrm{m}{ }^{-2} \mathrm{~s}^{-1} ; *=$ Night defined as whenever PAR $\leq 100 \mu \mathrm{mol} \mathrm{m}^{-2} \mathrm{~s}^{-1}$

PAR are the primary driving forces of the sea-air fluxes in the mesocosms. Thus, the flux derived from the mesocosms gives an idea of how important ocean biology and PAR can be for the marine emissions and/or uptake of the different VOCs. All the oceanic VOC budget estimates, except perhaps DMS, are based on the few measurements conducted in the "open" oceans in "selected" oceanic regions which have been extrapolated to the global oceans (references in Table 5), although conditions vary widely and vastly from one part of the global ocean to the other. Given this current uncertainty in VOC fluxes from/to the ocean (as highlighted in Table 5), the fluxes from this study can be used to "tentatively extrapolate" for an "indication of the possible global flux" for comparison with previous budget estimates and to ascertain which species are most significant for atmospheric chemistry.

Although this study took place in coastal waters, chlorophyll a $\left(2.28-1.05 \mu \mathrm{g} \mathrm{L}^{-1}\right.$, nutrient values $\quad\left(\mathrm{PO}_{4}^{3-}=0.05 \mu \mathrm{mol} \mathrm{L}^{-1} ; \quad \mathrm{NO}_{3}^{-}=1 \mu \mathrm{mol} \mathrm{L}^{-1}\right.$; $\mathrm{SiO}_{3}^{-}=0.25 \mu \mathrm{molL} L^{-1}$, Riebesell et al., 2007 $)$ and dissolved organic matter (DOM; 97-110 $\mu \mathrm{mol} \mathrm{L}^{-1}$ ) measured in the mesocosm seawater between 31 May and 10 June are representative of vast areas of the global oceans. The up-scaling of the fluxes was based on the entire global ocean surface area of $3.61 \times 10^{14} \mathrm{~m}^{2}$, and all results are summarized in Table 5.

For methanol we estimate a net oceanic sink of $2.97 \mathrm{Tg}$

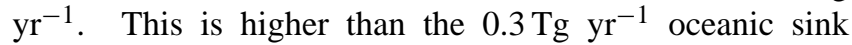
proposed by Galbally and Kirstine et al. (2002) and lower than the estimates reported by Singh et al. (2003), Heikes et al. (2002) and Jacob et al. (2005). Based on the same

\footnotetext{
${ }^{1}$ Riebesell, U., Schulz, K. G., Bellerby, R. G. J., Botros, M., Fritsche, P., Meyerhöfer, M., Neill, C., Nondal, G., Oschlies, A., Wohlers, J., and Zöllner, E.: Enhanced biological carbon consumption in a high $\mathrm{CO} 2$ ocean, in preparation, 2007.
}

measurements but different models, methanol oceanic sinks of $8 \mathrm{Tg} \mathrm{yr}^{-1}$ and $15 \mathrm{Tg} \mathrm{yr}^{-1}$ were proposed by Singh et al. (2003) and Singh et al. (2004), respectively, showing that different model parameterizations give quite different results.

Except for Jacob et al. (2002), all previous studies have estimated a net oceanic sink for acetone. We estimate an emission flux and uptake flux of $3.13 \mathrm{Tg} \mathrm{yr}^{-1}$ and $0.68 \mathrm{Tg} \mathrm{yr}^{-1}$, respectively. It should be mentioned that during the period of our field study in Norway, there was $18 \mathrm{~h}$ of daylight and only $6 \mathrm{~h}$ of darkness. As established in this study, acetone emissions are influenced by both a critical PAR threshold and biological activities, parameters that have not been incorporated in up-scaling the measurements obtained in this or previous studies.

Measurements of acetaldehyde are currently viewed with some scepticism due to recently reported potential sampling problems for this species. Apel et al. (2003) reported an artefact for acetaldehyde could occur within inlets, even on inert surfaces. Interferences in stratospherically influenced air have been reported by Northway et al. (2004) and Singh et al. (2004) for PTR-MS and GC systems, respectively, suggesting an interfering surface related phenomenon affecting all instruments. Furthermore, acetaldehyde measurements appear to be inconsistent with simultaneously measured species such as PAN and ethane when compared with models (Singh et al., 2004; Lewis et al., 2005). However, by measuring the difference in the acetaldehyde mixing ratios, for the inflowing ambient air and the mesocosm air, we have minimized possible systematic artefacts. As an additional precaution, all the Teflon inlets used for sampling ambient air and mesocosm air, had the same dimensions and were shrouded from sunlight, using black tubing. The case for acetaldehyde emission not being an artefact is strengthened as it correlates with both isoprene and the independently measured biological trends. Our estimate of a global acetaldehyde oceanic source of $2.62 \mathrm{Tg} \mathrm{yr}^{-1}$ is significantly 
Table 5. Comparison with earlier works on Marine Emissions and Uptake of VOCs.

\begin{tabular}{|c|c|c|c|c|c|}
\hline $\begin{array}{l}\text { Med./Ave* } \\
\left(\mathrm{nmol} \mathrm{mol}^{-1}\right)\end{array}$ & $\begin{array}{l}\text { Sea-Air } \\
\text { flux } \\
\left(\mathrm{ng} \mathrm{m}^{-2} \mathrm{~s}^{-1}\right)\end{array}$ & $\begin{array}{l}\text { Oceanic } \\
\text { Source } \\
\left(\operatorname{Tg~yr}^{-1}\right)\end{array}$ & $\begin{array}{l}\text { Oceanic } \\
\text { Sink } \\
\left(\operatorname{Tg~yr}^{-1}\right)\end{array}$ & Location & Reference \\
\hline \multicolumn{6}{|l|}{ Methanol } \\
\hline 0.87 & $-12.5^{\mathrm{a}}$ & - & - & Tropical Atlantic & Williams et al. (2004b) \\
\hline 0.57 & $-0.6^{\mathrm{a}}$ & - & 8 & Pacific Ocean (0-2 km) & Singh et al. (2003) \\
\hline 0.57 & - & - & 15 & Pacific Ocean (0-2 km) & Singh et al. (2004) \\
\hline 2.0 & $-2.81^{\mathrm{a}}$ & - & - & New England Marine Coast & Mao et al. (2006) \\
\hline 0.9 & - & $30^{\mathrm{b}}$ & 85 & - & Heikes et al. (2002) \\
\hline- & - & - & 0.3 & - & Galbally and Kirstine (2002) \\
\hline- & - & - & 10 & - & Jacob et al. (2005) \\
\hline 1.86 & $-0.26^{+}$ & - & 2.97 & Raunefjord, Norway & This work \\
\hline \multicolumn{6}{|l|}{ Acetone } \\
\hline 0.52 & $5.71^{\mathrm{a}}$ & - & - & Tropical Atlantic & Williams et al. (2004b) \\
\hline 1.3 & $-3.22^{\mathrm{a}}$ & - & - & New England Marine Coast & Mao et al. (2006) \\
\hline 0.47 & $-1.2^{\mathrm{a}}$ & - & 14 & Pacific Ocean $(0-2 \mathrm{~km})$ & Singh et al. (2003) \\
\hline 0.36 & $-2.92^{\mathrm{a}}$ & - & 48 & North Pacific Ocean & Marandino et al. (2005) \\
\hline 0.38 & - & - & - & Caribbean Sea & Zhou et al. (1993) \\
\hline- & - & 27 & 14 & - & Jacob et al. (2002) \\
\hline 0.5 & - & - & - & Mace Head & Lewis et al. (2005) \\
\hline 0.8 & $\begin{array}{l}-0.06^{+}(\mathrm{U}) \\
0.27^{+}(\mathrm{E})\end{array}$ & 3.13 & 0.68 & Raunefjord, Norway & This work \\
\hline \multicolumn{6}{|l|}{ Acetaldehyde } \\
\hline 0.2 & $11^{\mathrm{a}}$ & 125 & - & Pacific Ocean (0-2 km) & Singh et al. (2003) \\
\hline 0.44 & - & - & - & Mace Head & Lewis et al. (2005) \\
\hline 0.50 & - & - & - & Caribbean Sea & Zhou et al. (1993) \\
\hline 0.55 & $0.23^{+}$ & 2.62 & - & Raunefjord, Norway & This work \\
\hline \multicolumn{6}{|l|}{ Isoprene } \\
\hline 0.04 & $0.02-0.24^{\mathrm{a}}$ & $0.26-2.7$ & - & NW Pacific Ocean & Matsunaga et al. (2002) \\
\hline- & $0.02^{\mathrm{a}}$ & 0.22 & - & Near shore North Sea & Broadgate et al. (1997) \\
\hline- & $0.12^{\mathrm{a}}$ & 1.4 & - & NW Pacific Ocean & Bonsang et al. (1992) \\
\hline$<0.01$ & $0.01-0.08^{\mathrm{a}}$ & $0.08-0.9$ & - & Florida Straits & Milne et al. (1995) \\
\hline- & - & $0.1-0.7$ & - & North Atlantic & Baker et al. (2000) \\
\hline- & - & 0.12 & - & - & Palmer et al. (2005) \\
\hline 0.18 & $0.12^{+}$ & 1.4 & - & Raunefjord, Norway & This work \\
\hline \multicolumn{6}{|c|}{$\begin{array}{l}\text { Dimethyl sul- } \\
\text { phide }\end{array}$} \\
\hline 0.05 & $1.79^{\mathrm{a}}$ & - & - & Tropical Atlantic & Williams et al. (2004b) \\
\hline- & $1.44-4.3^{\mathrm{a}}$ & - & - & Equatorial Pacific Ocean & Huebert et al. (2004) \\
\hline $0.03-0.34$ & - & - & - & Southern Indian Ocean & Sciare et al. (2000) \\
\hline- & - & $29-104^{\mathrm{d}}$ & - & - & Andreae et al. (1990) \\
\hline- & - & $25-72^{\mathrm{d}}$ & - & - & Kettle et al. (2000) \\
\hline- & - & $50.37^{\mathrm{d}}$ & - & - & Nguyen et al. (1978) \\
\hline 0.4 & $0.3^{+}$ & $3.42^{\mathrm{d}}$ & - & Raunefjord, Norway & This work \\
\hline
\end{tabular}

$\mathrm{a}=$ converted from original units to $\left(\mathrm{ng} \mathrm{m}^{-2} \mathrm{~s}^{-1}\right) ; \mathrm{b}=$ best estimate; $+=$ average of median values in duplicate mesocosms; $\mathrm{d}=\mathrm{converted}$

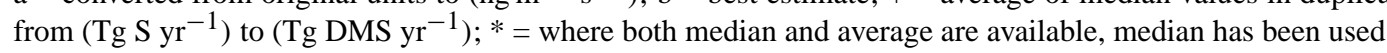


lower than the only other estimate of $125 \mathrm{Tg} \mathrm{yr}^{-1}$ reported by Singh et al. (2003). It should be noted that a direct emission of acetaldehyde through biological processes as suggested here is a good explanation why acetaldehyde levels were not consistent with ethane (formerly considered the main precursor) in the marine boundary layer.

Estimated global marine isoprene fluxes extrapolated from in-situ measurements range from $0.1-1.4 \mathrm{Tg} \mathrm{yr}^{-1}$ (Bonsang et al., 1992; Broadgate et al., 1997; Matsunaga et al., 2002; Shaw et al., 2003; Broadgate et al., 2004). The latest estimate based on satellite chlorophyll observations totals $0.12 \mathrm{Tg} \mathrm{yr}^{-1}$ (Palmer and Shaw, 2005). This is small in comparison with terrestrial emissions of ca. $500 \mathrm{Tg} \mathrm{yr}^{-1}$ and the results of this study $\left(1.4 \mathrm{Tg} \mathrm{yr}^{-1}\right)$ are in agreement with this estimate.

Dimethyl sulphide fluxes reported in this study (3.42 $\mathrm{Tg} \mathrm{yr}^{-1}$ ) are significantly lower than those reported in previous open ocean studies $\left(25-104 \mathrm{Tg} \mathrm{yr}^{-1}\right.$; Nguyen et al., 1978; Andreae, 1990; Kettle and Andreae, 2000; Sciare et al., 2000; Huebert et al., 2004). Two factors may contribute to the difference between the flux estimates of this study and previous studies. Firstly, measurements being in the aftermath of a phytoplankton bloom, characterized by depleting nutrients and generally moribund phytoplankton populations, DMS emissions are expected to be low. Alternatively it could be that the predominant biological species during our measurement period were not prolific DMS emitters.

\section{Conclusion}

From the discussion above it is clear that the air-sea flux of each trace gas depends differently on light and biological activity. Therefore on a global scale, extremely large variations in such fluxes can be expected as a consequence of the range of solar and biological conditions over the oceans. From the extensive ocean studies done on DMS emission fluxes, it is also apparent that seasonality and biological hotspots (such as upwelling at coasts or oceanic fronts) are very important factors. Thus, specifically parameterized models constrained by measurements from locations that represent the varied geographical areas of the global ocean are needed to form more accurate estimates of the oceanic contribution to the global budgets of different volatile organic compounds. This study has shown that PAR and ocean biology can act as quite important players in the emissions of acetone, acetaldehyde and isoprene from the ocean to the atmosphere. Photochemical and global ocean models that consider ethane to be the main source of acetaldehyde in the marine boundary layer may be able to resolve discrepancies between measured and modeled acetaldehyde concentrations by considering the additional biological source. The strong correlations between the daytime emission fluxes of acetone, acetaldehyde and isoprene may also be useful for modeling the air- sea emission fluxes of these VOCs. Possible methanol uptake at night by phytoplankton species must be investigated in future studies, as this could be a major source of methanol undersaturation in the global oceans. In order to further improve our understanding of the biogeochemical cycling of VOCs at the sea-air interface, we recommend that in future mesocosm experiments, both aqueous and gas phase concentrations should be monitored and the mesocosm air should be actively circulated with a fan to ensure thorough mixing in the gas phase. Further, a more exhaustive suite of biological parameters, measured at a higher frequency than in this study may yield valuable insights for biological production and/or consumption of VOCs in the seawater. Finally, the results have shown that the mesocosm approach is a new and novel technique, particularly suited for clarifying the vast uncertainties that exist in the field of Ocean VOC uptake and emissions and their biogeochemical cycling.

Acknowledgements. We wish to thank K. Schulz for the temperature data from the mesocosms. The authors also thank members of the ORSUM group and PeECE III participants, in particular, R. Hofmann, T. Klüpfel, N. Yassaa and A. Colomb for assistance in installation on the raft. G. Eerdekens and P. Bernhardt are acknowledged for help in designing the hexapus sampling system. V. Sinha would like to thank the International Max Planck Research School for granting a Research Fellowship.

This work was completed as preparation for the OOMPH experiment (http://www.atmosphere.mpg.de/enid/oomph)

Edited by: N. Mihalopoulos

\section{References}

Andreae, M.: Ocean-Atmosphere Interactions in the global biogeochemical sulphur cycle, Mar. Chem., 30(1-3), 1-29, 1990.

Apel, E., Hills, A., Lueb, R., Zindel, S., Eisele, S., and Riemer, D.: A fast-GC/MS system to measure C-2 to C-4 carbonyls and methanol aboard aircraft, J. Geophys. Res.-Atmos., 108(D20), 8794-8811, 2003.

Barlow, R. G., Cummings, D. G., and Gibb, S. W.: Improved resolution of mono- and divinyl chlorophylls a and $\mathrm{b}$ and zeaxanthin and lutein in phytoplankton extracts using reverse phase C-8 HPLC, Mar. Ecol. Prog., Ser. 161, 303-307, 1997.

Bonsang, B., Polle, C., and Lambert, G.: Evidence for Marine production of isoprene, Geophys. Res. Lett., 19(11), 1129-1132, 1992.

Broadgate, W., Liss, P., and Penkett, S.: Seasonal emissions of isoprene and other reactive hydrocarbon gases from the ocean, Geophys. Res. Lett., 24(21), 2675-2678, 1997.

Broadgate, W., Malin, G., Kupper, F., Thompson, A., and Liss, P.: Isoprene and other non-methane hydrocarbons from seaweeds: a source of reactive hydrocarbons to the atmosphere, Mar. Chem. 88(1-2), 61-73, 2004.

Carpenter, L. J., Lewis, A. C., Hopkins, J. R., Read, K. A., Longley, I. D., and Gallagher, M. W.: Uptake of methanol to the North Atlantic Ocean surface, Global Biogeochem. Cycles, 18, GB4027, doi:10.1029/2004GB002294, 2004. 
Colomb, A., Williams, J., Crowley, J., Gros, V., Hofmann, R., Salisbury, G., Kluepfel, T., Kormann, R., Stickler, A., Forster, C., and Lelieveld J.: Airborne measurements of trace organic species in the upper troposphere over Europe: the impact of deep convection, Environ.Chem., 3, 244-259, doi:10.1071/EN06020, 2006.

Dacey, J. and Wakeham, S.: Oceanic dimethyl sulfide - production during zooplankton grazing on phytoplankton, Science, 233(4770), 1314-1316, 1986.

Derenbach, J.: Zur Homogenisation des Phytoplanktons für die Chlorophyllbestimmung, Kieler Meeresforschungen, XXV(1), 166-171, 1969.

de Laat, A., de Gouw, J., Lelieveld, J., and Hansel, A.: Model analysis of trace gas measurements and pollution impact during INDOEX, J. Geophys. Res.-Atmos., 106(D22), 28 469-28 480, 2001

Engel, A., Zondervan, I., Aerts, K., Beaufort, L., Benthien, A., Chou, L., Delille, B., Gattuso, J., Hailay, J., Heemann, C., Hoffmann, L., Jacquet, S., Nejstgaard, J., Pizay, M., Rochelle-Newall, E., Schneider, U.,Terbrueggen, A., and Riebessell, U.: Testing the direct effect of $\mathrm{CO} 2$ concentration on a bloom of the coccolithophoroid Emiliania huxleyi in mesocosm experiments, Limnol. Oceanogr., 50(2), 493-507, 2005.

Field, C., Behrenfeld, M., Randerson, J., and Falkowski, P.: Primary production of the biosphere: Integrating terrestrial and oceanic components, Science, 281(5374), 237-240, 1998.

Gabric, A., Whetton, P., and Cropp, R.: Dimethylsulphide production in the subantarctic southern ocean under enhanced greenhouse conditions, Tellus B, 53(3), 273-287, 2001.

Galbally, I. and Kirstine, W.: The production of methanol by flowering plants and the global cycle of methanol, J. Atmos. Chem., 43(3), 195-229, 2002.

Guenther, A., Hewitt, C., Erickson, D., Fall, R., Geron, C., Graedel, T., Harley, P., Klinger, L., Lerdau, M., Mckay, W., Pierce, T., Scholes, B., Steinbrecher, R., Tallamraju, R., Taylor, J., and Zimmerman, P.: A global-model of natural volatile organiccompound emissions, J. Geophys. Res.-Atmos., 100(D5), 88738892,1995

Heikes, B., Chang, W., Pilson, M., Swift, E., Singh, H., Guenther, A., Jacob, D., Field, B., Fall, R., Riemer, D., and Brand, L.: Atmospheric methanol budget and ocean implication, Global Biogeochem. Cycles, 16(4), 1133-1146, 2002.

Huebert, B., Blomquist, B., Hare, J., Fairall, C., Johnson, J., and Bates, T.: Measurement of the sea-air DMS flux and transfer velocity using eddy correlation, Geophys. Res. Lett., 31(23), L23113,, doi:10.1029/2004GL021567 2004.

Jacob, D., Field, B., Jin, E., Bey, I., Li, Q., Logan, J., Yantosca, R., and Singh, H.: Atmospheric budget of acetone, J. Geophys. Res.-Atmos., 107(D10), 4100-4117, 2002.

Jacob, D., Field, B., Li, Q., Blake, D., de Gouw, J., Warneke, C., Hansel, A., Wisthaler, A., Singh, H., and Guenther, A.: Global budget of methanol: Constraints from atmospheric observations, J. Geophys. Res.-Atmos., 110(D8), 590-595, 2005.

Karl, T., Harley, P., Guenther, A., Rasmussen, R., Baker, B., Jardine, K., and Nemitz, E.: The bi-directional exchange of oxygenated VOCs between a loblolly pine (Pinus taeda) plantation and the atmosphere, Atmos. Chem. Phys., 5, 3015-3031, 2005, http://www.atmos-chem-phys.net/5/3015/2005/.

Kettle, A. and Andreae, M.: Flux of dimethylsulfide from the oceans: A comparison of updated data seas and flux models, J.
Geophys. Res.-Atmos., 105(D22), 26 793-26 808, 2000.

Kiene, R. P.: Microbial sources and sinks for methylated sulfur compounds in the marine environment, in: Microbial growth on C1 Compounds, 15-33, edited by: Kelly, D. P. and Murrell, J. C., Intercept Ltd., London, 1993.

Lewis, A., Hopkins, J., Carpenter, L., Stanton, J., Read, K., and Pilling, M.: Sources and sinks of acetone, methanol, and acetaldehyde in North Atlantic marine air, Atmos. Chem. Phys., 5, 1963-1974, 2005, http://www.atmos-chem-phys.net/5/1963/2005/.

Lindinger, W., Hansel, A., and Jordan, A.: Proton-transfer-reaction mass spectrometry (PTR-MS): on-line monitoring of volatile organic compounds at pptv levels, Chem. Soc. Rev., 27(5), 347354, 1998.

Liss, P. and Mervilat, L.: Air-sea gas exchange rates: Introduction and synthesis, in: The Role of Air-Sea Exchange in Geochemical Cycling, edited by: Buat-Menard, P. and Reidel, D., Norwell, Mass., 1986.

Mao, H., Talbot, R., Nielsen, C., and Sive, B.: Controls on methanol and acetone in marine and continental atmospheres, Geophys. Res. Lett., 33(2), L02803-L02807, 2006.

Marandino, C., De Bruyn, W., Miller, S., Prather, M. and Saltzman, E.: Oceanic uptake and the global atmospheric acetone budget, Geophys. Res. Lett., 32(15), L15806, doi:10.1029/2005GL023285, 2005.

Marie, D., Brussaard, C. P. D., Partensky, F., and Vaulot, D.: Enumeration of phytoplankton, bacteria and viruses in marine samples, in: Current protocols in cytometry, edited by: Robinson, J. P., Darzynkiewicz, Z., Dean, P. N., Orfao, A., Rabinovitch, P. Tanke, H., and Wheeless, L., John Wiley \& Sons, Chichester, pp. 11.11.1-11.11.15, 1999a.

Marie, D., Brussard, C., Thyrhaug, R.,Bratbak, G., and Vaulot, D.: Enumeration of marine viruses in culture and natural samples by flow cytometry, Appl. Environ. Microb., 65, 45-52, 1999b.

Matsunaga, S., Mochida, M., Saito, T., and Kawamura, K.: In situ measurement of isoprene in the marine air and surface seawater from the western North Pacific, Atmos. Environ., 36(39-40), 6051-6057, 2002.

McKeen, S., Gierczak, T., Burkholder, J., Wennberg, P., Hanisco, T., Keim, E., Gao, R., Liu, S., Ravishankara, A., and Fahey, D.: The photochemistry of acetone in the upper troposphere: A source of odd-hydrogen radicals, Geophys. Res. Lett., 24(24), 3177-3180, 1997.

Milne, P., Riemer, D., Zika, R., and Brand, L.: Measurement of vertical-distribution of isoprene in surface seawater, its chemical fate, and its emission from several phytoplankton monocultures, Mar. Chem., 48(3-4), 237-244, 1995.

Nguyen, B., Gaudry, A., Bonsang, B., and Lambert, G.: Reevaluation of role of dimethyl sulfide in sulfur budget, Nature, 275(5681), 637-639, 1978.

Nguyen, B. C., Belviso, S., Mihalopoulos, N., Gostan, J., and Nival, P.: Dimethylsulfide production during natural phytoplankton blooms, Mar. Chem., 24, 133-141, 1988.

Northway, M., de Gouw, J., Fahey, D., Gao, R., Warneke, C., Roberts, J., and Flocke, F.: Evaluation of the role of heterogeneous oxidation of alkenes in the detection of atmospheric acetaldehyde, Atmos. Environ., 38(35), 6017-6028, 2004.

Olivier, J. G. J., Bouwman, A. F., Vandermass, C. W. M., and Berdowski, J. J. M.: Emission database for global atmospheric 
research (EDGAR), Environ. Monit. Assess., 31(1-2), 93-106, 1994.

Palmer, P. and Shaw, S.: Quantifying global marine isoprene fluxes using MODIS chlorophyll observations, Geophys. Res. Lett., 32(9), L09805-L09810, 2005.

Salisbury, G., Williams, J., Holzinger, R., Gros, V., Mihalopoulos, N., Vrekoussis, M., Sarda-Esteve, R., Berresheim, H., von Kuhlmann, R., Lawrence, M., and Lelieveld, J.: Ground-based PTR-MS measurements of reactive organic compounds during the MINOS campaign in Crete, July-August 2001, Atmos. Chem. Phys., 3, 925-940, 2003, http://www.atmos-chem-phys.net/3/925/2003/.

Sciare, J., Mihalopoulos, N., and Dentener, F.: Interannual variability of atmospheric dimethylsulfide in the southern Indian Ocean, J. Geophys. Res.-Atmos., 105(D21), 26 369-26377, 2000.

Shaw, S., Chisholm, S., and Prinn, R.: Isoprene production by Prochlorococcus, a marine cyanobacterium, and other phytoplankton, Mar. Chem., 80(4), 227-245, 2003.

Singh, H., Chen, Y., Staudt, A., Jacob, D., Blake, D., Heikes, B., and Snow, J.: Evidence from the Pacific troposphere for large global sources of oxygenated organic compounds, Nature, 410(6832), 1078-1081, 2001.

Singh, H., Chen, Y., Tabazadeh, A., Fukui, Y., Bey, I., Yantosca, R., Jacob, D., Arnold, F., Wohlfrom, K., Atlas, E., Flocke, F., Blake, D., Blake, N., Heikes, B., Snow, J., Talbot, R., Gregory, G., Sachse, G., Vay, S., and Kondo, Y.: Distribution and fate of selected oxygenated organic species in the troposphere and lower stratosphere over the Atlantic, J. Geophys. Res.-Atmos., 105(D3), 3795-3805, 2000

Singh, H., Ohara, D., Herlth, D., Sachse, W., Blake, D., Bradshaw, J., Kanakidou, M., and Crutzen, P.: Acetone in the atmosphere - Distribution, Sources and Sinks, J. Geophys. Res.Atmos., 99(D1), 1805-1819, 1994.
Singh, H., Salas, L., Chatfield, R., Czech, E., Fried, A., Walega, J., Evans, M., Field, B., Jacob, D., Blake, D., Heikes, B., Talbot, R., Sachse, G., Crawford, J., Avery, M., Sandholm, S., and Fuelberg, H.: Analysis of the atmospheric distribution, sources, and sinks of oxygenated volatile organic chemicals based on measurements over the Pacific during TRACE-P, J. Geophys. Res.Atmos., 109(D15), D15S07-D15S20, 2004.

Singh, H., Tabazadeh, A., Evans, M., Field, B., Jacob, D., Sachse, G., Crawford, J., Shetter, R., and Brune, W.: Oxygenated volatile organic chemicals in the oceans: Inferences and implications based on atmospheric observations and air-sea exchange models, Geophys. Res. Lett., 30(16), 1862-1867, 2003.

Tie, X., Guenther, A., and Holland, E.: Biogenic methanol and its impacts on tropospheric oxidants, Geophys. Res. Lett., 30(17), 1881-1885, 2003.

Williams, J.: Organic trace gases: An overview, Environ. Chem., 1, 125-136, 2004a.

Williams, J., Holzinger, R., Gros, V., Xu, X., Atlas, E., and Wallace, D.: Measurements of organic species in air and seawater from the tropical Atlantic, Geophys. Res. Lett., 31(23), L23S06, doi:10.1029/2004GL020012, 2004b.

Williams, J., Poschl, U., Crutzen, P., Hansel, A., Holzinger, R., Warneke, C., Lindinger, W., and Lelieveld, J.: An atmospheric chemistry interpretation of mass scans obtained from a proton transfer mass spectrometer flown over the tropical rainforest of Surinam, J. Atmos. Chem., 38(2), 133-166, 2001.

Williams, P. and Egge, J.: The management and behaviour of the mesocosms, Estuar Coast Shelf S., 46, 3-14, 1998.

Zhou, X. and Mopper, K.: Carbonyl-compounds in the lower marine troposphere over the Caribbean sea and Bahamas, J. Geophys. Res.-Oceans, 98(C2), 2385-2392, 1993.

Zhou, X. and Mopper, K.: Photochemical production of lowmolecular-weight carbonyl compounds in seawater and surface microlayer and their air-sea exchange, Mar. Chem., 56(3-4), 201-213, 1997. 